\title{
Ambient pressure photoemission spectroscopy reveals the mechanism of carbon soot oxidation in ceria-based catalysts
}

Lluís Soler, ${ }^{[\mathrm{a}]}$ Albert Casanovas, ${ }^{[\mathrm{a}]}$ Carlos Escudero, ${ }^{[\mathrm{b}]}$ Virginia Pérez-Dieste, ${ }^{[\mathrm{b}]}$ Eleonora Aneggi, ${ }^{[\mathrm{c}]}$ Alessandro Trovarelli, ${ }^{[\mathrm{c}]}$ Jordi Llorca, ${ }^{\text {[a] }}$

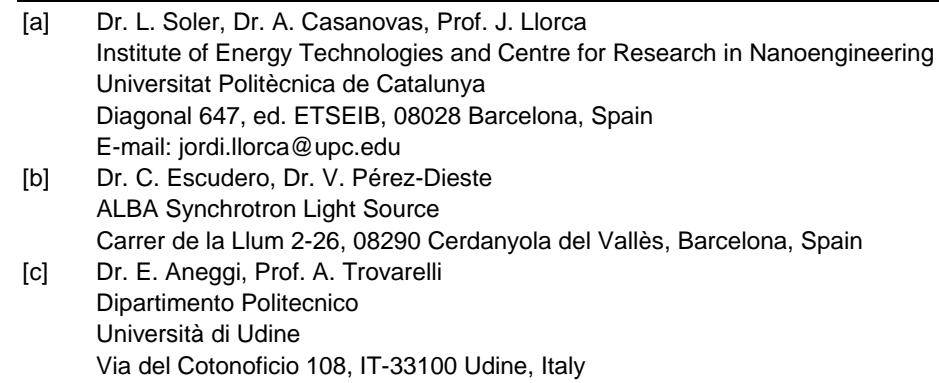

Abstract: Removing soot is one of the most important challenges in minimizing the impact of combustion engines on the environment. Catalysts based on $\mathrm{CeO}_{2}$ have proved suitable to oxidize soot due to their capacity to store and release oxygen easily while maintaining structural integrity, although their mode of operation in a complex environment involving two solid phases (catalyst and soot) and a gas phase (oxygen) is not yet fully understood. Here we provide a study of the surface/subsurface of ceria-soot and ceria-zirconia-soot mixtures under working conditions by means of near ambient pressure photoelectron spectroscopy. Soot abatement involves two cooperative routes: one occurring at the ceria-soot interface with formation of oxygen vacancies and Ce'", and another at the surface of soot mediated by active superoxide species, which result from the reaction between gas-phase $\mathrm{O}_{2}$ and oxygen vacancies. The two routes occur simultaneously and mutually reinforce each other.

Soot elimination constitutes a serious environmental and health concern as soot particles are undesired by-products formed in combustion processes and emitted as a main pollutant from diesel engines. Usually, particle traps are used for soot removal and, in order to avoid filter blocking, effective regeneration systems have been developed to oxidize soot. Thermal combustion of soot usually requires temperatures above $600^{\circ} \mathrm{C}$, and catalysts play a key role in lowering the ignition temperature. Ceria-based catalysts are among the most effective for diesel soot oxidation ${ }^{[1]}$ and incorporation of $\mathrm{Zr}$ and rare earth elements, particle morphology and ceria-soot interface have been demonstrated to be strongly involved in the dynamics of the reaction. ${ }^{[2]}$ It has been generally assumed that soot oxidation proceeds via a Mars-Van Krevelen mechanism. That is, lattice oxygen in the first few surface layers of ceria is transferred onto soot, and gaseous $\mathrm{O}_{2}$ fills up the vacancies created on the oxide in a further step. ${ }^{[3]}$ However, the mechanism of action has also been associated with the availability of adsorbed active oxygen species which spillover onto the soot 
surface. ${ }^{[3 a, 4]}$ Formation of paramagnetic $\mathrm{O}_{2}^{-}$superoxide species and diamagnetic $\mathrm{O}_{2}{ }^{2-}$ peroxide species has been claimed to occur when reduced $\mathrm{CeO}_{2-\mathrm{x}}$ is exposed to $\mathrm{O}_{2},{ }^{[5]}$ and it has been suggested that these are indeed the precursor surface species which are responsible for soot oxidation. ${ }^{[3 a, 6]}$ In the present study, we use operando ambient pressure X-ray photoelectron spectroscopy (AP-XPS) for the first time to study the surface of $\mathrm{CeO}_{2}$ and $\mathrm{Ce}_{0.8} \mathrm{Zr}_{0.2} \mathrm{O}_{2}$ catalysts during soot oxidation. AP-XPS is a unique surfacesensitive characterization tool essential to identify the active species at work in reducible oxides such as ceria-based materials, as the surface restructuring driven by the reaction environment induces strong changes in their architecture that cannot be followed under UHV conditions. ${ }^{[7]}$

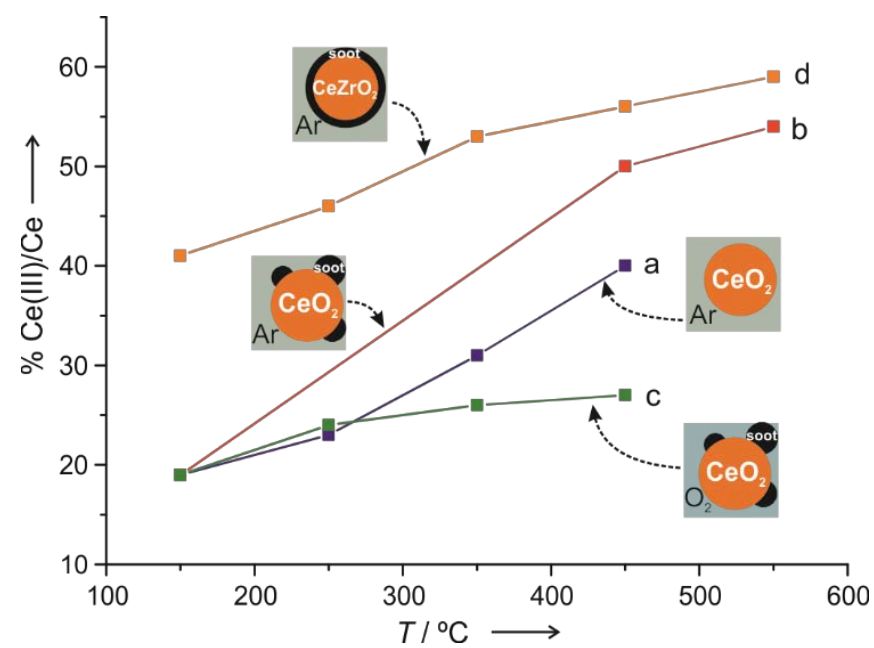

Figure 1. Amount of reduced ceria measured at different temperatures in bare $\mathrm{CeO}_{2}$ under $\mathrm{Ar}(\mathrm{a})$, in sample $\mathrm{CeO}_{2}$-soot under $\mathrm{Ar}$ (b), in sample $\mathrm{CeO}_{2}$-soot under $\mathrm{O}_{2}$ (c), and in sample $\mathrm{Ce}_{0.8} \mathrm{Zr}_{0.2} \mathrm{O}_{2}$-soot under $\mathrm{Ar}(\mathrm{d}$ ).

A sample of conventional ceria and a sample of $\mathrm{Ce}_{0.8} \mathrm{Zr}_{0.2} \mathrm{O}_{2}$ mixed with soot were investigated in this study. A sample of ceria without soot was used as blank. The mixing of the catalysts with carbon soot (weight ratio catalyst:soot of 20:1) was accomplished under conventional tight contact mode for $\mathrm{CeO}_{2}{ }^{[8]}$ and under supertight contact achieved by high-energy milling of $\mathrm{Ce}_{0.8} \mathrm{Zr}_{0.2} \mathrm{O}_{2}$ and soot for $8 \mathrm{~h} .{ }^{[\mathrm{b}]}$ Both materials crystallize in a cubic fluorite structure and exhibit similar surface area and particle size (Table S1). Soot clumps are easily recognized in the HRTEM images of the $\mathrm{CeO}_{2}$-soot sample, whereas highenergy milling of $\mathrm{Ce}_{0.8} \mathrm{Zr}_{0.2} \mathrm{O}_{2}$ and soot results in the formation of a core of oxide particles wrapped in a thin carbon envelope (Figure S1), in accordance with 
earlier reports. ${ }^{[2 b, 8]}$ This greatly increases the number and quality of contact points between the catalyst and carbon, shifting the combustion of soot to exceptionally low temperatures (Table S1).

Three operando AP-XPS experiments (ALBA synchrotron light source) were carried out at 1 mbar over $\mathrm{CeO}_{2}$ : (i) heating $\mathrm{CeO}_{2}$ from room temperature up to $450^{\circ} \mathrm{C}$ under Ar, to be used as blank experiment, (ii) heating the $\mathrm{CeO}_{2}$-soot mixture from room temperature up to $550^{\circ} \mathrm{C}$ under $\mathrm{Ar}$ and then replacing $\mathrm{Ar}$ with $\mathrm{O}_{2}$, and (iii) heating the $\mathrm{CeO}_{2}$-soot mixture from room temperature up to $550^{\circ} \mathrm{C}$ under $\mathrm{O}_{2}$. It is well known that heating $\mathrm{CeO}_{2}$ under inert atmosphere causes the formation of oxygen vacancies and the concomitant reduction of $\mathrm{Ce}^{\mathrm{IV}}$ to $\mathrm{C} \mathrm{e}^{\mathrm{III}}$. [9] As expected, Ce ${ }^{\text {III }}$ increased with temperature (Figures $1 \mathrm{a}$ and S2). However, in the presence of soot, ceria reduction was significantly higher (Figures 1 and 2), which means that ceria lattice oxygen atoms directly react with soot, in accordance with the Mars-Van Krevelen mechanism and with previous reports. ${ }^{[10]}$ This observation is also supported by the progressive decrease of the $\mathrm{C} / \mathrm{Ce}$ atomic ratio as the temperature increases $\left(\mathrm{C} / \mathrm{Ce}=24.4\right.$ at $450^{\circ} \mathrm{C}$ vs. 16.0 at $\left.550^{\circ} \mathrm{C}\right)$.

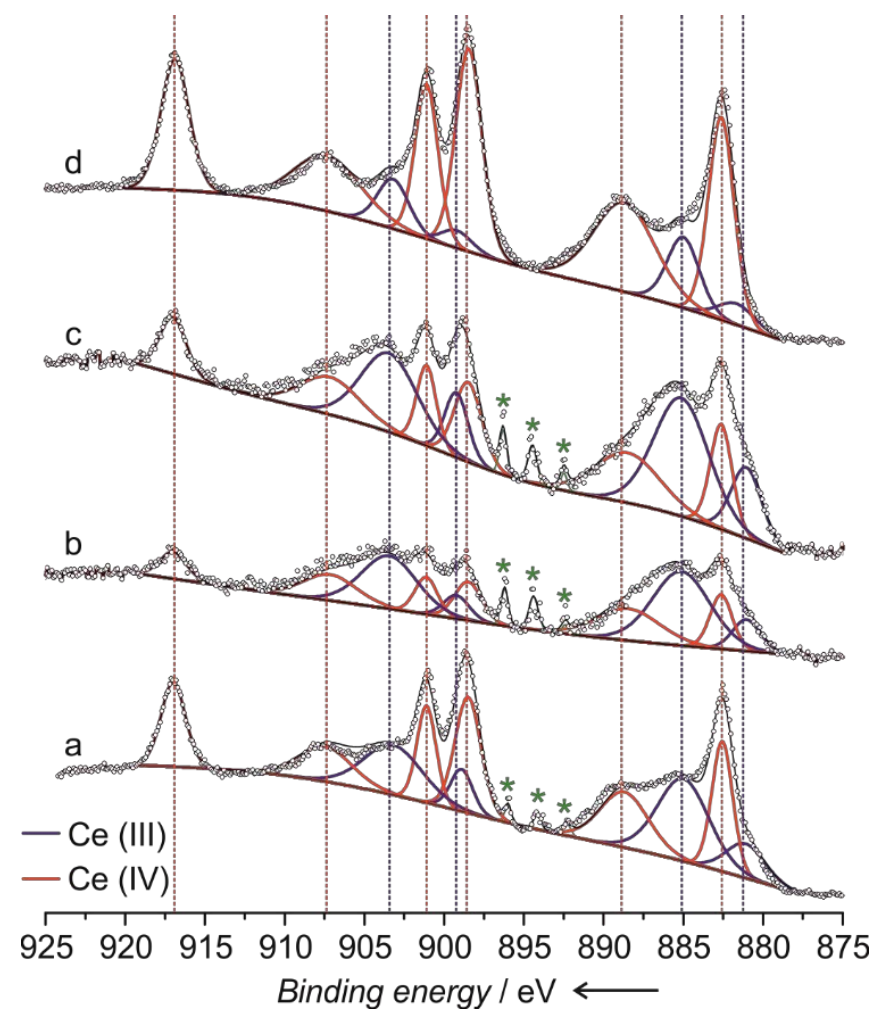

Figure 2. $\mathrm{Ce} 3 \mathrm{~d}$ spectra recorded over $\mathrm{CeO}_{2}$ under $\mathrm{Ar}$ at $450^{\circ} \mathrm{C}$ (a) and over $\mathrm{CeO}_{2}$-soot under $\mathrm{Ar}$ at $450^{\circ} \mathrm{C}$ (b), $550^{\circ} \mathrm{C}$ (c) and by replacing $\mathrm{Ar}$ with $\mathrm{O}_{2}$ at $550^{\circ} \mathrm{C}(\mathrm{d})$. ( $\star \mathrm{Ar}$ gas phase). 
At $550^{\circ} \mathrm{C}$, Ar was replaced with $\mathrm{O}_{2}$ and, as expected, Ce $\mathrm{ClI}^{\mathrm{III}}$ reoxidized to $\mathrm{Ce}^{\mathrm{IV}}$ to a large extent (Figure $2 d$ ), reducing the total amount of $\mathrm{Ce}^{\text {III }}$ from ca. 50 to $16 \%$. The introduction of oxygen on a heavily reduced ceria surface results, not only in the reoxidation of $\mathrm{Ce}^{\mathrm{III}}$, but also in a deep oxidation of residual soot (C/Ce from 16 to 2.9). Under Ar, the $\mathrm{O}$ 1s signal recorded at $528.7 \mathrm{eV}$ (Figure 3a) corresponds to ceria lattice oxygen, and the minor contribution at $530.7 \mathrm{eV}$ is ascribed to different ceria lattice oxygen environments upon vacancy formation. ${ }^{[11]}$ It should be mentioned that, in the presence of soot (Figure 3b), there is a broadening of the $\mathrm{O}$ 1s signal at high binding energies with respect to the spectrum of bare $\mathrm{CeO}_{2}$ (Figure 3a), pointing to a variety of surface/subsurface oxygen environments, which can be directly related with the higher amount of $\mathrm{Ce}^{\mathrm{III}}$ in the $\mathrm{CeO}_{2}$-soot sample (bare soot showed an $\mathrm{O} / \mathrm{C}$ ratio of only $\sim 0.04$, thus the contribution of soot to the $O 1$ s signal is negligible). Upon contact with oxygen, in addition to the peaks at 538.6 and $537.5 \mathrm{eV}$ corresponding to paramagnetic $\mathrm{O}_{2}$ in the gas phase, ${ }^{[12]}$ two peaks at 530.5 and $532.2 \mathrm{eV}$ appeared (Figure 3c). According to literature, these peaks are attributed to peroxide $\left(\mathrm{O}_{2}{ }^{2-}\right)$ and superoxide $\left(\mathrm{O}_{2}{ }^{-}\right)$species, respectively. ${ }^{[13]}$

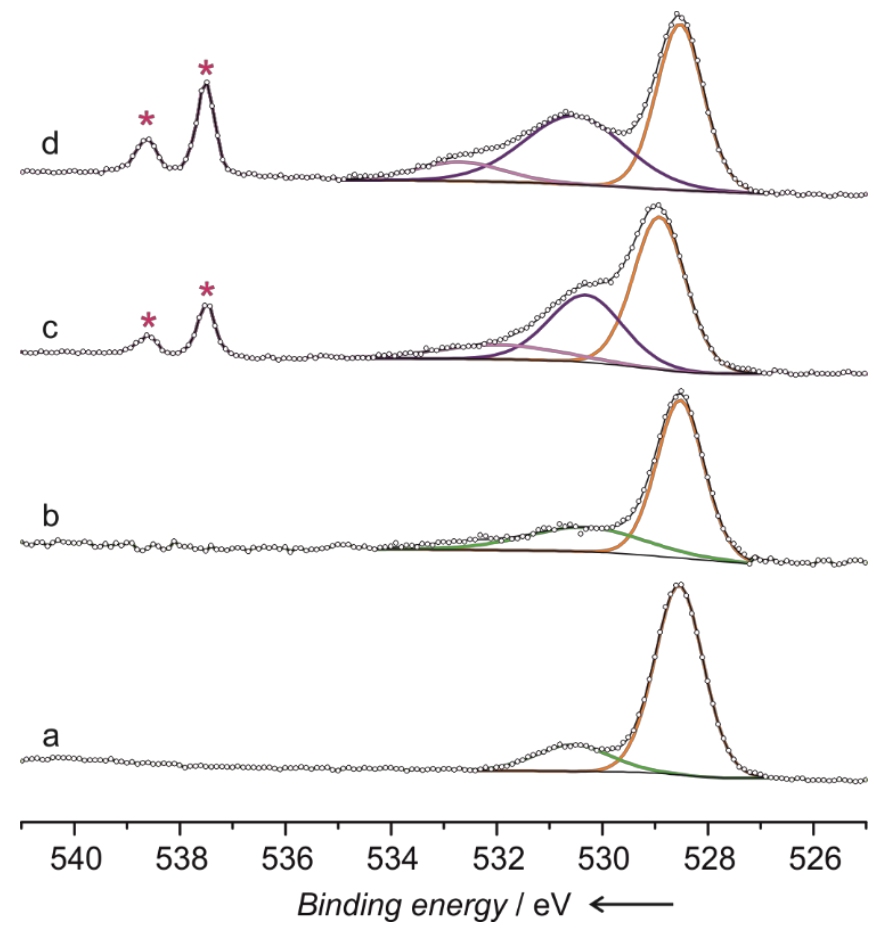

Figure 3. $\mathrm{O}$ 1s spectra recorded over $\mathrm{CeO}_{2}$ under $\mathrm{Ar}$ at $450^{\circ} \mathrm{C}$ (a) and over $\mathrm{CeO}_{2}$-soot at $550^{\circ} \mathrm{C}$ under $\mathrm{Ar}$ (b) and by replacing $\mathrm{Ar}$ with $\mathrm{O}_{2}$ at $550^{\circ} \mathrm{C}$ (c). Spectrum (d) corresponds to the $\mathrm{CeO}_{2}$-soot sample heated directly under $\mathrm{O}_{2}$ from ambient temperature. ( $\star \mathrm{O}_{2}$ gas phase). 
In a separate experiment, the $\mathrm{CeO}_{2}$-soot sample was heated from room temperature up to $550^{\circ} \mathrm{C}$ under $\mathrm{O}_{2}$ (Figure $1 \mathrm{c}$ and Figure S3). In this case, the amount of $\mathrm{Ce}^{\text {III }}$ species remained low over the entire temperature range, indicating that the oxygen vacancies created at the ceria-soot interface reacted rapidly with $\mathrm{O}_{2}$, as expected. As outlined above, the reaction between molecular $\mathrm{O}_{2}$ and the oxygen vacancies form active oxygen species $\left(\mathrm{O}_{2}{ }^{2-} \text { and } \mathrm{O}_{2}{ }^{-}\right)^{[14]}$ which were clearly seen in the $\mathrm{O} 1 \mathrm{~s}$ spectra of the experiment carried out under $\mathrm{O}_{2}$ (Figure 3d). The amount of $\mathrm{O}_{2}{ }^{-}$species observed in the experiment performed under $\mathrm{Ar}$ and then switched to an oxygen atmosphere was lower than that recorded in the experiment under $\mathrm{O}_{2}\left(\mathrm{O}_{2}{ }^{2-} / \mathrm{O}_{2}{ }^{2}=16.4\right.$ vs. 4.8), which might indicate a higher reactivity of the superoxide species toward soot oxidation than that of the peroxide species.
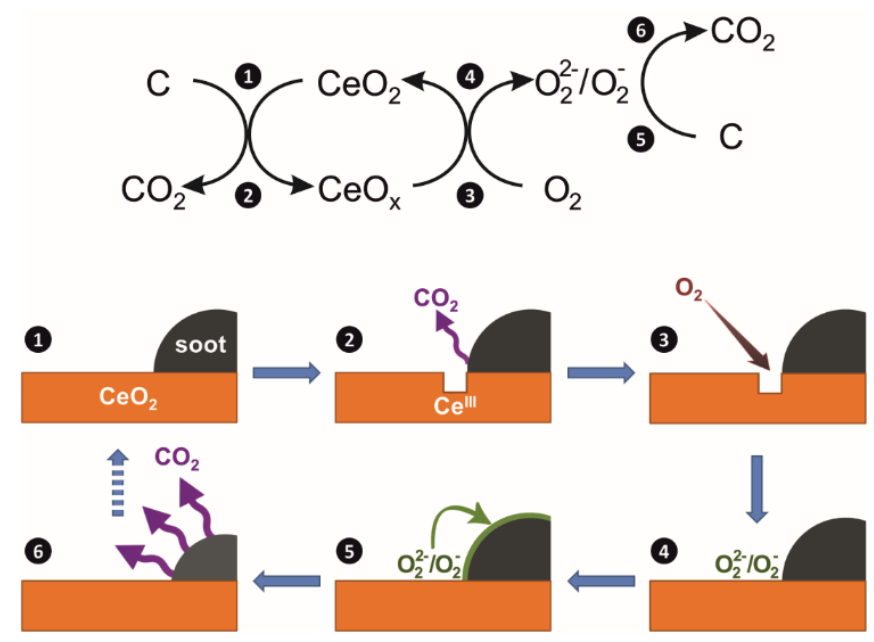

Scheme 1. Scheme of the mechanism of soot oxidation over ceria-based catalysts. 1-Reaction between soot and ceria at the contact points. 2-Formation of oxygen vacancies at the interface and release of $\mathrm{CO}_{2}$. 3-Reaction between $\mathrm{O}_{2}$ and oxygen vacancies. 4Reoxidation of ceria surface and formation of active oxygen species $\left(\mathrm{O}_{2}{ }^{-}\right.$and $\left.\mathrm{O}_{2}{ }^{2}{ }^{2}\right)$. 5-Spillover of active oxygen species onto soot. 6Reaction between soot and active oxygen species and release of $\mathrm{CO}_{2}$. The cycle starts over again at the new contact points between soot and ceria until soot is completely oxidized.

Our AP-XPS results support a mechanism where ceria is first reduced by soot at the interface between the carbon particles and the ceria surface releasing $\mathrm{CO}_{2}$, and then the reduced ceria surface reacts with gaseous oxygen refilling the oxygen vacancies and yielding peroxide/superoxide species. These active oxygen species likely migrate to the carbon surface and react efficiently to form $\mathrm{CO}_{2}$ at a much lower energy cost. Then, a new contact point between soot and the surface of ceria is established and the cycle starts over again (Scheme 1). To further validate this scheme, we studied $\mathrm{Ce}_{0.8} \mathrm{Zr}_{0.2} \mathrm{O}_{2}$-soot mixed under supertight conditions, which showed an extraordinary low soot 
combustion temperature (Table S1). ${ }^{[2 b]}$ The amount of Ce ${ }^{\text {III }}$ upon heating under $\mathrm{Ar}$ was, in all cases, higher than that recorded over the $\mathrm{CeO}_{2}$-soot sample (Figures $1 \mathrm{~b}, 1 \mathrm{~d}, 4 \mathrm{a}$, and $\mathrm{S} 4$ ). The $\mathrm{O} 1 \mathrm{~s}$ spectrum recorded under Ar showed three components at 528.7, 530.2 and 532.2 eV (Figure 4c). The peaks at 528.7 and $530.2 \mathrm{eV}$ correspond to lattice oxygen and surface oxide ions with low coordination resulting from vacancy formation, respectively. The peak at 532.2 $\mathrm{eV}$, attributed to superoxide species, was extraordinarily intense. At $550^{\circ} \mathrm{C}$, the Ar atmosphere was replaced with $\mathrm{O}_{2}$ and the amount of $\mathrm{Ce}^{\mathrm{III}}$ immediately decreased from ca. $60 \%$ to $23.5 \%$ (Figure $4 b$ ). At the same time, the $O 1$ s peak of surface oxide ions with low coordination associated to $\mathrm{Ce}^{\text {III }}$ present at the surface/subsurface (at $530.2 \mathrm{eV}$ ) decreased due to the reoxidation of ceria (Figure 4d). In addition, the superoxide signal at $532.1 \mathrm{eV}$ dominated the spectrum and the O/Ce ratio increased from 17.4 to 23.2, in agreement with FTIR and EPR measurements of previous reports, ${ }^{[15]}$ thus supporting the idea that the superoxide $\mathrm{O}_{2}{ }^{-}$species formed by reaction between molecular $\mathrm{O}_{2}$ and oxygen vacancies redistributed on the catalyst surface. 

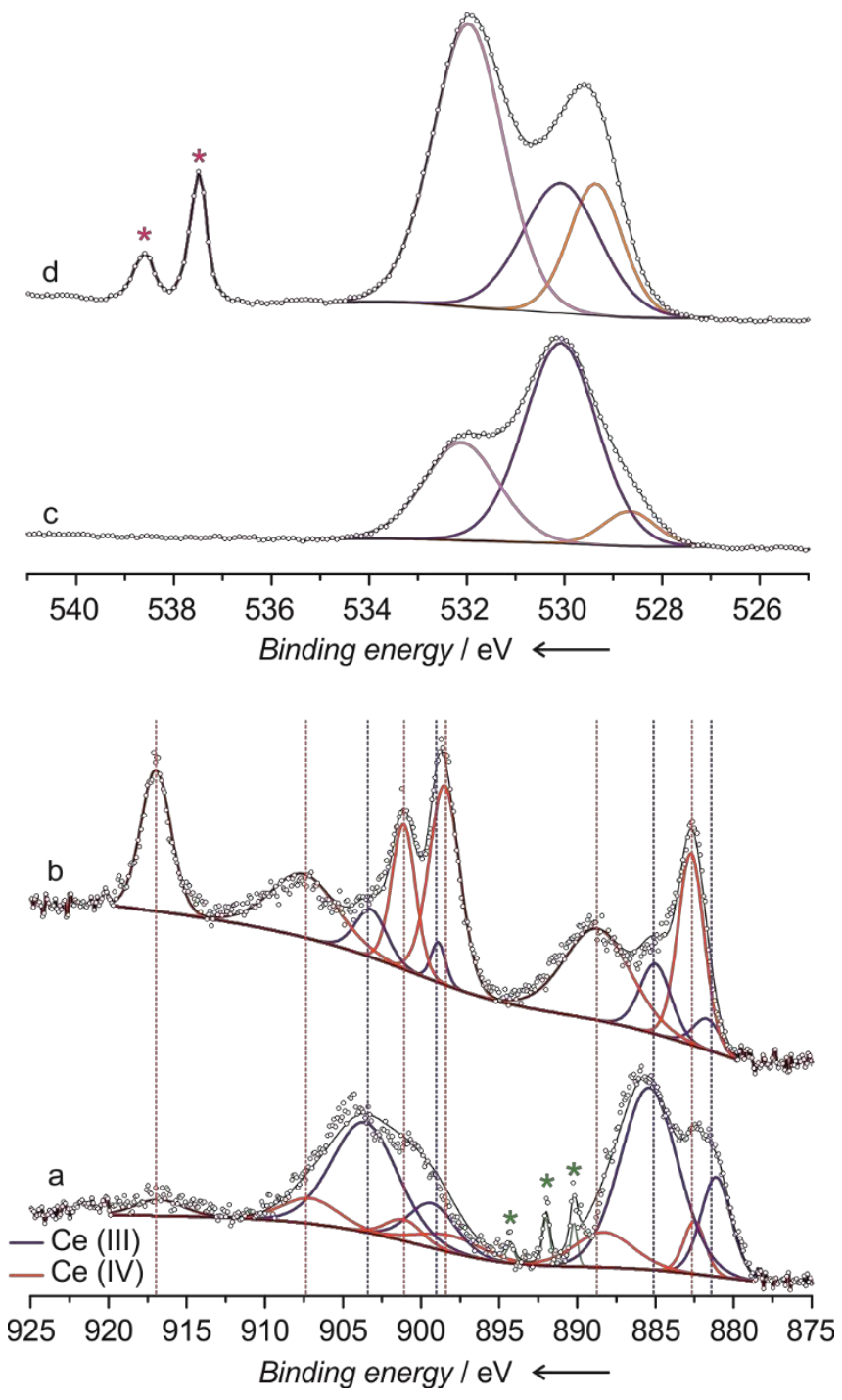

Figure 4. Ce $3 \mathrm{~d}$ and $\mathrm{O}$ 1s spectra recorded over $\mathrm{Ce}_{0.8} \mathrm{Zr}_{0.2} \mathrm{O}_{2}$-soot at $550^{\circ} \mathrm{C}$ under $\mathrm{Ar}(\mathrm{a}, \mathrm{c})$ and by replacing $\mathrm{Ar}$ with $\mathrm{O}_{2}$ (b,d). (green $\star$, $\mathrm{Ar}$ gas phase; pink $\star, \mathrm{O}_{2}$ gas phase).

We have provided by AP-XPS a direct measurement of the unique behaviour of the $\mathrm{Ce}^{\mathrm{III}} / \mathrm{C} \mathrm{e}^{\mathrm{IV}}$ redox chemistry and the influence of the reaction environment in the oxidation of carbon soot over ceria-based catalysts. The AP-XPS technique demonstrates the capacity of ceria to oxidize soot owing to the formation of oxygen vacancies with reduction of $\mathrm{Ce}^{\mathrm{IV}}$ to $\mathrm{Ce}^{\mathrm{III}}$, and the significant formation of active oxygen surface species due to the reaction of oxygen vacancies and molecular $\mathrm{O}_{2}$. A general two-way cooperative mechanism of soot oxidation over ceria-based materials has been therefore demonstrated, providing reliable information on the local characteristics of the surface/subsurface species involved in this complex heterogeneous solid/solid/gas catalytic process. 


\section{Experimental Section}

$\mathrm{CeO}_{2}$ and $\mathrm{Ce}_{0.8} \mathrm{Zr}_{0.2} \mathrm{O}_{2}$ were prepared by precipitation of an acidic solution of nitrate precursors with $\mathrm{NH}_{4} \mathrm{OH}$ in presence of $\mathrm{H}_{2} \mathrm{O}_{2}$. AP-XPS experiments were carried out at the CIRCE beamline of the ALBA synchrotron light source at a sample pressure of 1 mbar. A full description of the methodology is given in the SI.

\section{Acknowledgements}

This work has been funded through MINECO grant ENE2015-63969-R. L.S. is grateful to Generalitat de Catalunya for a Beatriu de Pinós grant (2013 BP-B 00007). J.L. is Serra Húnter Fellow and is grateful to ICREA Academia program. E.A. and A.T. are grateful to regione Friuli Venezia Giulia. The APXPS experiments were performed at CIRCE beamline at ALBA Synchrotron with the collaboration of ALBA staff.

Keywords: Soot combustion $•$ ceria catalysts $\bullet$ near ambient pressure photoelectron spectroscopy $\bullet$ oxygen storage $\bullet$ heterogeneous catalysis

a) A. Bueno-López, Appl. Catal. B Environ. 2014, 146, 1-11. b) D. Fino, S. Bensaid, M. Piumetti, N. Russo, Appl. Catal. A Gen. 2016, 509, 75-96. c) E. Aneggi, C. de Leitenburg, A. Trovarelli, in Catal. by Ceria Relat. Mater. 2nd Ed. (Eds.: A. Trovarelli, P. Fornasiero), Imperial College Press, London, 2013, pp. 565-621.

a) E. Aneggi, D. Wiater, C. De Leitenburg, J. Llorca, A. Trovarelli, ACS Catal. 2014, 4, 172-181. b) E. Aneggi, V. Rico-Perez, C. de Leitenburg, S. Maschio, L. Soler, J. Llorca, A. Trovarelli, Angew. Chemie Int. Ed. 2015, 54, 14040-14043. c) B. Bassou, N. Guilhaume, K. Lombaert, C. Mirodatos, D. Bianchi, Energy and Fuels 2010, 24, 4781-4792.

a) A. Bueno-López, K. Krishna, M. Makkee, J. A. Moulijn, J. Catal. 2005, 230, 237-248. b) K. Harada, T. Oishi, S. Hamamoto, T. Ishihara, J. Phys. Chem. C 2014, 118, 559-568.

a) G. Mul, F. Kapteijn, C. Doornkamp, J. A. Moulijn, J. Catal. 1998, 179, 258-266. b) G. Preda, A. Migani, K. M. Neyman, S. T. Bromley, F. Illas, G. Pacchioni, J. Phys. Chem. C 2011, 115, 5817-5822. c) J. Kullgren, K. Hermansson, P. Broqvist, J. Phys. Chem. Lett. 2013, 4, 604-608.

a) J. Xu, J. Harmer, G. Li, T. Chapman, P. Collier, S. Longworth, S. C. Tsang, Chem. Commun. 2010, 46, 1887-1889. b) J. Soria, A. Martinez-Arias, J. C. Conesa, J. Chem. Soc. Trans. 1995, 91, 1669-1678. c) V. V Pushkarev, V. I. Kovalchuk, J. L. D'Itri, J. Phys. Chem. B 2004, 108, 5341-5348. d) E. Saab, E. Abi-Aad, M. N. Bokova, E. A. Zhilinskaya, A. Aboukaïs, Carbon N. Y. 2007, 45, 561-567.

a) M. Machida, Y. Murata, K. Kishikawa, D. Zhang, K. Ikeue, Chem. Mater. 2008, 20, 4489-4494. b) M. S. Gross, M. A. Ulla, C. A. Querini, J. Mol. Catal. A Chem. 2012, 352, 86-94.

a) D. E. Starr, Z. Liu, M. Hävecker, A. Knop-Gericke, H. Bluhm, Chem. Soc. Rev. 2013, 42, 5833-5857. b) N. J. Divins, I. Angurell, C. Escudero, V. Pérez-Dieste, J. Llorca, Science 2014, 346, 620-623. c) K. Mudiyanselage, S. D. Senanayake, L. Feria, S. Kundu, A. E. Baber, J. Graciani, A. B. Vidal, S. Agnoli, J. Evans, R. Chang, et al., Angew. Chemie Int. Ed. 2013, 52, 5101-5105. d) N. J. Divins, J. Llorca, Appl. Catal. A Gen. 2015, DOI:10.1016/j.apcata.2015.08.018. e) D. R. Mullins, Surf. Sci. Rep. 2015, 70, 42-85.

[8] E. Aneggi, C. De Leitenburg, J. Llorca, A. Trovarelli, Catal. Today 2012, 197, 119-126.

[9] J. P. Holgado, G. Munuera, J. P. Espinós, A. R. González-Elipe, Appl. Surf. Sci. 2000, 158, 164-171.

[10] E. Aneggi, N. J. Divins, C. De Leitenburg, J. Llorca, A. Trovarelli, J. Catal. 2014, 312, 191-194.

[11] R. Jain, A. Dubey, M. K. Ghosalya, C. S. Gopinath, Catal. Sci. Technol. 2016, 6, 1746-1756. 
[12] S. Blomberg, M. J. Hoffmann, J. Gustafson, N. M. Martin, V. R. Fernandes, A. Borg, Z. Liu, R. Chang, S. Matera, K. Reuter, et al., Phys. Rev. Lett. 2013, 110, 117601.

[13] a) M. Strongin, S. L. Qiu, J. Chen, C. L. Lin, E. M. McCarron, Phys. Rev. B 1990, 41, 7238-7240. b) M. Fu, X. Yue, D. Ye, J. Ouyang, B. Huang, J. Wu, H. Liang, Catal. Today 2010, 153, 125-132. c) Y. Wei, J. Liu, Z. Zhao, A. Duan, G. Jiang, C. Xu, J. Gao, H. He, X. Wang, Energy Environ. Sci. 2011, 4, 2959-2970.

[14] a) C. Li, K. Domen, K. Maruya, T. Onishi, J. Am. Chem. Soc. 1989, 111, 7683-7687. b) A. Trovarelli, Catal. Rev. 1996, 38, 439-520. c) X. Zhang, K. J. Klabunde, Inorg. Chem. 1992, 31, 1706-1709.

[15] a) S. Rossignol, F. Gérard, D. Duprez, J. Mater. Chem. 1999, 9, 1615-1620. b) A. Martínez-Arias, M. Fernández-García, C. Belver, J. C. Conesa, J. Soria, Catal. Letters 2000, 65, 197-204. 